obtained for one locality cannot be fully applied to another, much less extended to determine the temperature at the superior limit of the atmosphere.

An interesting point of resemblance between Mr. Hall's observations and those made on the Himalaya is that the diurnal range of temperature diminishes to a minimum at about 5000 feet, and then increases with increasing elevation.

Allahabad, March 30

S. A. HILL

\section{Royal Society's Soirée}

MAY I be permitted, through the columns of NATURE, to ask, on behalf of the Sub-Committee appointed to make arrangements for the forthcoming soirée of the Royal Society, that Fellows and others who have apparatus or objects of scientific interest suitable for exbibition on that occasion will communicate at once with the Secretaries or myself.

Royal Society, Burlington House

HERBERT Rix, Asst. Sec. R.S.

\section{HOMERIC ASTRONOMY}

II.

\section{$\mathrm{T}$} URNING to the second great constellation mentioned in both Homeric epics, we again meet traces of remote and unconscious tradition. Yet less remote, probably, than that concerned with the Bear. Certainly less inscrutable. For recent inquiries into the lore and language of ancient Babylon have thrown much light on the relationships of the Orion fable.

There seems no reason to question the validity of Mr. Robert Brown's interpretation of the word by the Accadian Ur-ana, "light of heaven" ("Myth of Kirke," p. 146). But a proper name is significant only where it originates. Moreover, it is considered certain that the same brilliant star-group known to Homer no less than to us as. Orion, was termed by Chaldeo-Assyrian peoples "Tammuz" (Lenormant, Origines "de l'Histoire, t. i. p. 24i), a synonym of Adonis. Nor is it difficult to divine how the association came to be established. For about 2000 B.C., when the Euphratean constellations assumed their definitive forms, the belt of Orion began to be visible before dawn in the month of June, called "Tammuz," because the death of Adonis was then celebrated. It is even conceivable that the heliacal rising of the asterism may originally have given the signal for that celebration. We can at any rate scarcely doubt that it received the name of "Tammuz" because its annual emergence from the solar beams coincided with the period of mystical mourning for the vernal sun.

Orion, too, has solar connexions. In the Fifth "Odyssey" (12I-24), Calypso relates to Hermes how the love for him of Aurora excited the jealousy of the gods, extinguished only when he fell a victim to it, slain by the shafts of Artemis in Ortygia. Obviously, a sun-and-dawn myth slightly modified from the common type. The post-Homeric stories, too, of his relations with CEnopion of Chios, and of his death by the bite of a scorpion (emblematical of darkness, like the boar's tusk in the Adonis legend), confirm his position as a luminous hero (R. Brown, Archceologia, vol. xlvii. p. 352; "Great Dionysiak Myth," chap. x. §v.). Altogether, the evidence is strongly in favour of considering Orion as a variant of Adonis, imported into Greece from the East at an early date, and there associated with the identical group of stars which commemorated to the Accads of old the fate of Dumuzi (i.e. Tammuz), the "Only Son of Heaven."

It is remarkable that Homer knows nothing of stellar mythology. He nowhere attempts to account for the names of the stars. He has no stories at his fingers' ends of translations to the sky as a ready means of exit from terrestrial difficulties. The Orion of his acquaintance-the beloved of the Dawn, the mighty hunter, surpassing in beauty of person even the divinely-born Aloidæ

$$
\text { I Continued from p. } 588 \text {. }
$$

-died and descended to Hades like other mortals, and was there seen by Ulysses, a gigantic shadow "driving the wild beasts together over the mead of asphodel, the very beasts which he himself had slain on the lonely hills, with a strong mace all of bronze in his hand, that is ever unbroken ("Odyssey," xi. 572-75). His stellar connexion is treated as a fact apart. The poet does not appear to feel any need of bringing it into harmony with the Odyssean vision.

The brightest star in the heavens is termed by Homer the "dog of Orion." The name Seirios (significant of sparkling), makes its début in the verses of Hesiod. To the singer of the "Iliad" the dog-star is a sign of fear, its rising giving presage to "wretched mortals" of the intolerable, feverish blaze of late summer (opora). The deadly gleam of its rays hence served the more appropriately to exemplify the lustre of havoc-dealing"weapons. Diomed, Hector, Achilles, "all furnish'd, all in arms," are compared in turn, by way of prelude to an "aristeia," or culminating epoch of distinction in battle, to the same brilliant but baleful object. Glimmering fitfully across clouds, it not inaptly typifies the evanescent light of the Trojan hero's fortunes, no less than the flashing of his armour, as he moves restlessly to and fro ("Iliad," xi. $62-6)$. Of Achilles it is said :-

" Him the old man Priam first beheld, as he sped across the plain, blazing as the star that cometh forth at harvesttime, and plain seen his rays shine forth amid the host of stars in the darkness of night, the star whose name men call Orion's Dog. Brightest of all is he, yet for an evil sign is he set, and bringeth much fever upon hapless men. Even so on Achilles' breast the bronze gleamed as he ran" (xxii. 25-32).

In the corresponding passage relating to Diomed (v. 4-7), the naive literalness with which the "baths of Ocean" are thought of is conveyed by the hint that the star shone at rising with increased brilliancy through having newly washed in them.

Abnormal celestial appearances are scarcely noticed in the Homeric poems. There are neither eclipses ${ }^{1}$ of sun or moon, nor comets, nor star-showers. The rain of blood, by which Zeus presaged and celebrated the death of Sarpedon ("Iliad," xvi. 459, also xi. 54) might be thought to embody a reminiscence of a crimson aurora, frequently, in early times, chronicled under that form ; but the portent indicated is more probably an actual shower of rain tinged red by a microscopic alga. An unmistakable meteor, however, furnishes one of the glowing similes of the "Iliad." By its help the irresistible swiftness and unexpectedness of Athene's descent from Olympus to the Scamandrian plain are illustrated.

"Even as the son of Kronos the crooked counsellor sendeth a star, a portent for mariners or a wide host of men, bright shining, and therefrom are scattered sparks in multitude; even in such guise sped Pallas Athene to earth, and leapt into their midst " ("Iliad," iv. 75-9).

In the Homeric verses the Milky Way-the "path of souls" of prairie-roving Indians, the mediæval "way of pilgrimage "2 - finds no place. Yet its conspicuousness, as seen across our misty air, gives an imperfect idea of the lustre with which it spans the translucent vault which drew the wondering gaze of the Ionian bard.

The point of most significance about Homer's scanty astronomical notions is that they were of home growth. They are precisely such as would arise among a people in an incipient stage of civilisation, simple, direct, and childlike in their mode of regarding natural phenomena, yet incapable of founding upon them any close or connected reasoning. Of Oriental mysticism there is not a vestige. No occult influences rain from the sky. Not so

I Görlitz finds a prediction of a solar eclipse at "Odyssey," xx. 357 ; but the expression appears quite indefinite and figurative.

2 To Compostella. The popular Gernan name for the Milky Way is still Jakobsstrasse, while the three stars of Orion's beit are designated, in the same connexion, Jakobsstab, staff of St. James. 
much as a square inch of foundation is laid for the astrological superstructure. It is true that Sirius is a "baleful star"; but it is in the sense of being a harbinger of hot weather. Possibly, or probably, it is regarded as a concomitant cause, no less than as a sign of the August droughts ; indeed the post hoc and the propter hoc were, in those ages, not easily separable ; the effect, however, in any case, was purely physical, and so unfit to become the starting-point of a superstition.

The Homeric names of the stars, too, betray common reminiscences rather than foreign intercourse. They are all either native, or naturalised on Greek soil. The transplanted fable of Orion has taken root and flourished there. The cosmopolitan Bear is known by her familiar Greek name. Boötes is a Greek husbandman, variously identified with Arkas, son of Callisto, or with Ikaros, the luckless mandatory of Dionysos. The Pleiades and the Hyades are intelligibly designated in Greek. The former word is usually derived from plein, to sail ; the heliacal rising of the "tangled" stars in the middle of May having served, from the time of Hesiod, to mark the opening of the season safe for navigation, and their cosmical setting, at the end of October, its close. But this etymology was most likely an after-thought. Long before rules for navigating the Ægean came to be formulated, the "sailing-stars" must have been designated by name amongst the Achaian tribes. Besides, Homer is ignorant of any such association. Now in Arabic the Pleiades are called Eth Thuraiyâ, from therwa, copious, abundant. The meaning conveyed is that of many gathered into a small space ; and it is quite similar to that of the Biblical kimah, a near connexion of the Assyrian kimtu, family (R. Brown, "Phainomena of Aratus," p. 9; Delitzsch, "The Hebrew Language," p. 69). Analogy, then, almost irresistibly points to the interpretation of Pleiades by the Greek pleîones, many, or pleîos, full ; giving to the term, in either case, the obvious signification of a "cluster."

Of the Hyades, similarly, the "rainy" association seems somewhat far-fetched. They rise and set respectively about four days later than the Pleiades; so that, as prognostics of the seasons, it would be difficult to draw a permanent distinction between the two groups; yet one was traditionally held to bring fair, the other foul weather. There can be little doubt that an etymological confusion lay at the bottom of this inconsistency. "To rain," in Greek is huein; but hus (cognate with "sow") means a "pig." Moreover, in old Latin, the Hyades were called Sucula ("little pigs"); although the misapprehension which he supposed to be betrayed by the term was rebuked by Cicero ( $D e$ Nat. Deorum, lib. ii. cap. 43). Possibly the misapprehension was the other way. It is quite likely that "Suculæ" preserved the original meaning of "Hyades," and that the pluvious derivation was invented at a later time, when the conception of the seven stars in the head of the Bull as a "litter of pigs" had come to appear incongruous and inelegant. It has, nevertheless, just that character of naïveté which stamps it as authentic. Witness the popular names of the sistergroup-the widely-diffused "hen and chickens," Sancho Panza's "las siete cabrillas," met and discoursed with during his famous aërial voyage on the back of Clavileño, the Sicilian "seven dovelets,"--all designating the Pleiades. Still more to the purpose is the Anglo-Saxon "boarthrong," which, by a haphazard identification, has been translated as Orion, but which Grimm, on better grounds, suggests may really apply to the Hyades (Teutonic Mythology, trans. by J. S. Stallybrass, vol. ii. p. 729). It is scarcely credible that any other constellation can be indicated by a term so manifestly reproducing the "Suculæ" of Latin and Sabine husbandmen.

The Homeric scheme of the heavens, then, (such as it is), was produced at home. No stellar lore had as yet been imported from abroad. An original community of ideas is just traceable in the names of some of the stars; that is all. The epoch of instruction by more learned neighbours was still to come. The Signs of the Zodiac were certainly unknown to Homer, yet their shining array had been marshalled from the banks of the Euphrates at least 2000 years before the commencement of the Christian era. Their introduction into Greece is attributed to Cleostratus of Tenedos, near, or shortly after, the end of the sixth century B.C. By that time, too, acquaintance had been made with the "Phœnician" constellation of the Lesser Bear, and with the wanderings of the planets. Astronomical communications, in fact, began to pour into Hellas from Egypt, Babylonia, and Phœnicia about the seventh century B.C. Now, if there were any reasonable doubt that "blind Melesigenes" lived at a period anterior to this, it would be removed by the consideration of what he lets fall about the heavenly bodies. For, though he might have ignored formal astronomy, he could not have remained unconscious of such striking and popular facts as the identity of Hesperus and Phosphorus, the Sidonian pilots' direction of their course by the "Cynosure," or the mapping-out of the sun's path among the stars by a series of luminous figures of beasts and men.

Thus the hypothesis of a late origin tor the "Iliad" and "Odyssey" is negatived by the astronomical ignorance betrayed in them. It has, however, gradations; whence some hints as to the relative age of the two epics may be derived. The differences between them in this respect are, it is true, small, and they both stand approximately on the same astronomical level with the poems of Hesiod. Yet an attentive study of what they have to tell us about the stars affords some grounds for placing the "Iliad" the "Odyssey," and the "Works and Days" in a descending series as to time.

In the first place, the division of the month into three periods of ten days each is unknown in the "Iliad," is barely hinted at in the "Odyssey," but is brought into detailed notice in the Hesiodic calendar. Further, the "turning-points of the sun" are unmentioned in the "Iliad," but serve in the "Odyssey," by their position on the horizon, to indicate direction; while the winter solstice figures as a well-marked epoch in the "Works and Days." Hesiod, moreover, designates the dog-star (not expressly mentioned in the "Odyssey") by a name of which the author of the "Iliad" was certainly ignorant. Besides which an additional constellation (Boötes) to those named in the "Iliad" appears in the "Odyssey" and the "Works and Days"; while the title "Hyperion," applied substantively to the sun in the "Odyssey," is used only adjectivally in the "Iliad." Finally, steilar mythology begins with Hesiod; Homer (whether the Ionian or the Ithacan) takes the names of the stars as he finds them, without seeking to connect them with any sublunary occurrences.

To be sure, differences of place and purpose might account for some of these discrepancies, yet their cumulative effect in fixing relative epochs is considerable; and, even apart from chronology, it is something to look towards the skies with the "most high poet," and to retrace, with the aid of our own better knowledge, the simple meanings their glorious aspect held for him.

\section{A. M. CleRKE}

\section{ON ICE AND BRINES'}

I.

THE composition of the ice produced in saline solutions, and more particularly in sea-water, has frequently been the object of investigation and of dispute. It might be thought that to a question of whether ice so formed does or does not contain salt, experiment would at once give a decisive answer. Yet, relying on experiment alone, competent authorities have given contradictory answers. All

I Paper read before the Royal Society of Edinburgh, by J. Y. Buchanan on March 27 last. 